\title{
SOME QUANTITATIVE ASPECTS OF NATURAL BABESIAL INFECTION IN THE HAEMOLYMPH OF BOOPHILUS MICROPLUS ENGORGED FEMALE TICKS
}

\author{
GUGLIELMONE A.A.*, GAIDO A.B.**, AGUIRRE D.H.*** \& CAFRUNE M.M.***
}

\section{Summary :}

Quantitative aspects of the natural babesial (Babesia bovis and Babesia bigeminal infection in Boophilus microplus engorged female ticks obtained from two herds of Holstein heifers positive by the immunofluorescent antibody test to both protozoan were evaluated. The number of kinetes/microscope field of haemolymph was determined for each tick from day 5 to 10 post-collection. A close relationship between daily and cumulative babesial infection was detected. Correlation and determination coefficients between days post-collection and the daily and cumulative infection rates, including heavily infected ticks (those ticks carrying at least 3.0 kinetes/ microscope field of haemolymph), were always higher than $0.9(P<0.01)$ in ticks of both herds. The median was found to be a more representative measure than the mean to define the distribution of kinetes number amongst infected ticks since this is a negative binomial distribution. The analysis of the sequential order of days of infection more accurately showed the amplification of the babesial infection in the tick haemolymph than the evolution of kinetes number in relation to days post-collection. Sampling ticks on days 8,9 and 10 post-collection would have detected all ticks infected with Babesia spp. from both herds. A categorization of infected or non infected ticks would be of greater epidemiological importance than the haemolymph infection level, based upon previous laboratory studies that showed a poor relationship between haemolymph infection in the female ticks and the infection rate in their eggs. However, further studies in natural infected ticks and better techniques to differentiate $B$. bovis and B. bigemina kinetes are needed before these laboratory results can be applied to field conditions.

KEY WORDS : Boophilus microplus, Babesia bovis, Babesia bigemina haemolymph infection, quantitative aspects.

MOTS CLÉS : Boophilus microplus, Babesia bovis, Babesia bigemina infection de l'hémolymphe, aspects quantitatifs.
Résumé : QuelQues ASPECTS QUANTITATIFS DE L'INFECTION BABÉSIENNE NATURELLE DE L'HÉMOLYMPHE DES FEMELLES GORGÉES DE LA TIQUE BOOPHILUS MICROPLUS

On a étudié les aspects quantitatifs de l'infection babésienne naturelle (Babesia bovis et Babesia bigemina) chez des femelles gorgées de Boophilus microplus récoltées dans deux troupeaux de génisses Holstein présentant des anticorps spécifiques aux deux espèces de Babesia, selon le test d'immunofluorescence. Le nombre de kinètes/champ microscopique d'hémolymphe est établi pour chaque tique entre le $5^{e}$ et le $10^{e}$ jour après sa récolte. On a trouvé une corrélation étroite entre les infections journalières et les infections cumulées par Babesia. Les coefficients de corrélation et de détermination entre les jours post-récolte et les taux d'infection journalière et cumulée, y compris pour les tiques très infectées /celles qui ont eu au moins 3,0 kinètes/champ microscopique d'hémolymphe), ont été toujours supérieurs à 0,9 $(P<0,01)$ chez les tiques des deux troupeaux. La médiane a été une mesure plus représentative que la moyenne pour définir la distribution du nombre des kinètes chez les tiques infectées, étant donné qu'il s'agit d'une distribution binomiale négative. L'analyse de l'ordre séquentiel des jours d'infection a montré plus précisément l'amplification de l'infection babésienne de l'hémolymphe des tiques, par rapport à l'évolution du nombre des kinètes en relation avec les jours post-récolte. L'évaluation aux $8^{e}$, ge et $10^{\circ}$ jours postrécolte pourrait avoir décélé toutes les tiques infectées par Babesia spp. dans les deux troupeaux. L'importance épidémiologique de la différenciation entre des tiques infectées et non infectées pourrait être supérieure aux niveaux d'infection de l'hémolymphe, en accord avec les études préalables qui ont démontré une faible relation entre l'infection des tiques et le taux d'infection de leurs œufs. Néanmoins, d'autres recherches sont nécessaires avec des tiques naturellement infectées et des techniques plus spécifiques pour différencier les kinètes de $\mathrm{B}$. bovis et de B. bigemina, avant que les résultats de ce travail puissent être utilisés dans les infestations naturelles.

\footnotetext{
* Instituto Nacional de Tecnología Agropecuaria, Estación Experimental Agropecuaria Rafaela, CC 22, 2300 Rafaela (Santa Fe), Argentina

** Consejo Nacional de Investigaciones Científicas y Técnicas, Estación Experimental Agropecuaria Salta, CC 228, 4400 Salta, Argentina.

**** Instituto Nacional de Tecnología Agropecuaria, Estación Experimental Agropecuaria Salta, CC 228, 4400 Salta, Argentina.

Correspondence : A.B. Gaido.
}

INTRODUCTION

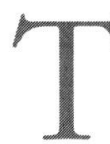

he babesial infection in the vector tick is an important aspect of the epidemiology of cattle babesiosis (Babesia bovis and Babesia bigemina), disease mainly transmitted by ticks of the genus Boophilus (Friedhoff, 1988). Rosenbusch (1927) observed that few Boophilus microplus engorged 
females were heavily infected with $B$. bigemina kinetes, and recently Gaido \& Guglielmone (1995) found a negative binomial distribution of the number of Babesia spp. kinetes amongst naturally infected B. microplus female ticks. They also reported an increasing infection rate directly related to time post detachment, probably coupled to the continuous release of kinetes into the haemolymph after sporogony occurs (Friedhoff, 1988). Other characteristic of the natural babesial infection in B. microplus engorged female ticks is the lack of obvious harmful effects associated to the level of the haemolymph babesial infection (Guglielmone et al., 1989; Cafrune et al., 1993; Gaido \& Guglielmone, 1995) allowing tick monitoring throughout the life period of this tick stage to study the Babesia-Boophilus relationship.

In this article we further analyse quantitative aspects of the daily and cumulative babesial infection in B. microplus engorged female ticks fed on Holstein heifers sero-positive by the immunofluorescent antibody test to B. bovis and B. bigemina (Ríos et al., 1988). We also used field data as an aid in determining sampling periods of $B$. microplus engorged female ticks to detect babesial infection.

\section{MATERIALS AND METHODS}

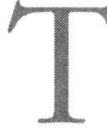

he ticks were obtained from two herds (A and B) located within the Argentinean area infested with $B$. microplus in the province of Salta. Farms coordinates, number of ticks collected, laboratory tick maintenance, haemolymph sampling technique and quantitation of babesial infection were detailed previously (Gaido \& Guglielmone, 1995).

Samples of haemolymph were obtained from all ticks from day 5 to 10 post collection. The evolution of daily and cumulative babesial infection of ticks from both herds was analysed. Correlation and determination coefficients between days post collection and daily and cumulative infection rates of total ticks carrying Babesia spp. kinetes of each herd were obtained. The same coefficients were determined for heavily infected ticks, defined as those carrying at least 3.0 kinetes/microscope field of haemolymph (Guglielmone et al., 1989). The number of kinetes/microscope field of haemolymph was assessed to obtain the median, the first and third quartils, along with the mean and standard deviation of the infected ticks to broadly compare these positional and dispersion measures. Additionally, these parameters were determined considering the sequential order of infection days (i.e., the values of the first day of infection were arranged in the same column regardless the day post collection on which these first infections were detected, next column contained the values of the second day of infection and so forth to the sixth day of infection).

Chi square analysis was applied to the proportion of ticks of both herds carrying less than 0.3 kinetes/microscope field at first detection of infection and on the sixth day. Also judging that several ticks from both herds were first found infected on day 10 post collection, the cumulative days that would had been needed to detect all the infected ticks starting on day 10 post collection were determined.

\section{RESULTS}

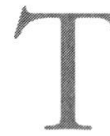

otals of 54 and 35 infected B. microplus engorged female ticks were collected from herd $\mathrm{A}$ and $\mathrm{B}$, respectively. The relationship of daily and cumulative babesial infection of all infected ticks from both herds is shown in figure 1. Correlation and determination coefficients for the infected ticks of each herd are presented in table I. The number and percentage of ticks from the two herds found first infected in relation to days post collection, including the absolute number of heavily infected ticks on the corresponding day, are presented in table II.

The mean, standard deviation, median, quartils and range of kinetes/microscope field of haemolymph of ticks from both herds in relation to day post collection and to the sequential days of infection are shown in table III.

Forty two $(77.7 \%)$ and $27(77.1 \%)$ of the infected ticks of herd A and B, respectively, showed less than

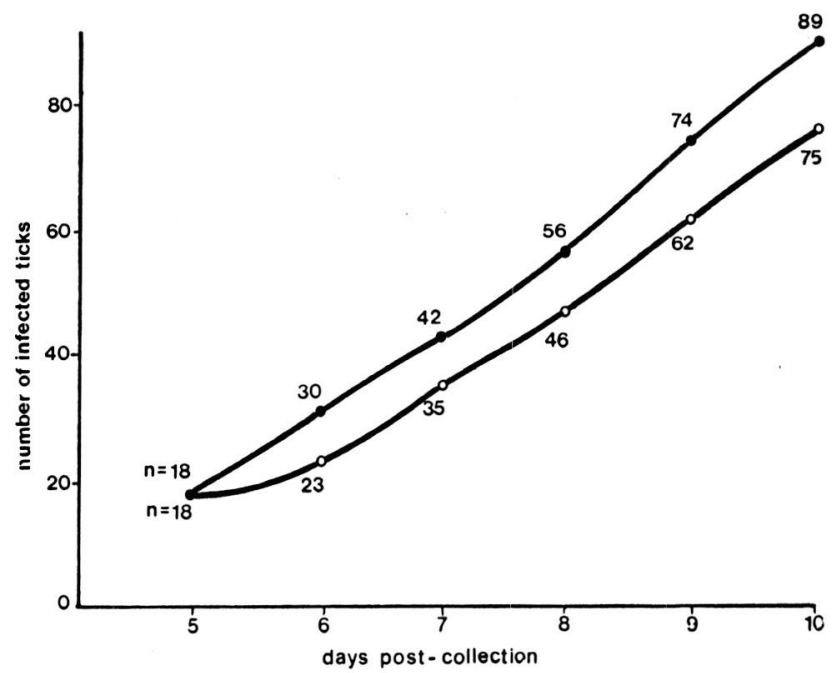

Fig. 1. - Number of Boophilus microplus engorged female ticks carrying kinetes of Babesia spp. in their haemolymph on a daily (o) and cumulative ( $)$ basis. Pooled results from ticks obtained from two herds of Holstein heifers. 


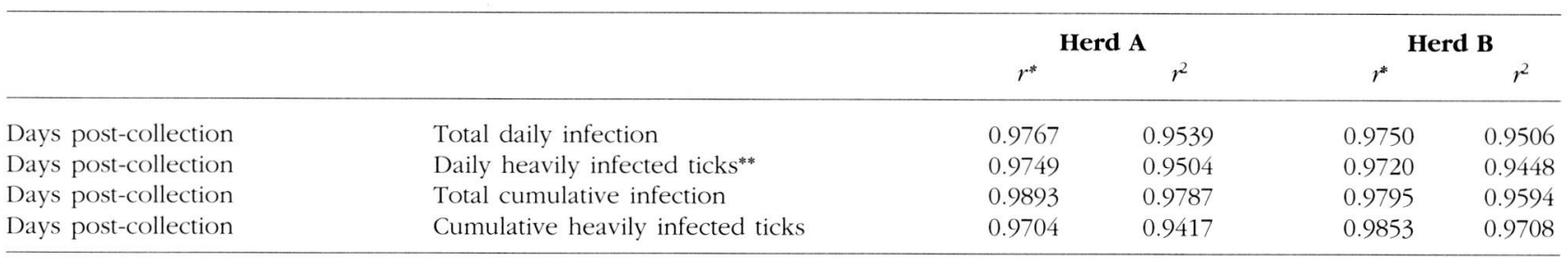

* All P $<0.01$

** Heavily infected ticks defined as those ticks carrying at least 3.0 kinetes per microscope field of haemolymph (Guglielmone et al., 1989).

Table I. - Correlation $(r)$ and determination $\left(r^{2}\right)$ coefficients of daily and cumulative haemolymph infection with kinetes of Babesia spp. in Boophilus microplus engorged female ticks from two herds of Holstein heifers in relation to days 5 to 10 post-collection.

\begin{tabular}{|c|c|c|c|c|}
\hline \multirow[b]{2}{*}{ Day post-collection } & \multicolumn{2}{|c|}{$\begin{array}{l}\text { No and }(\%) \text { of ticks found infected } \\
\text { for the first time }\end{array}$} & \multicolumn{2}{|c|}{$\begin{array}{c}\text { No of ticks } \\
\text { heavily infected* }\end{array}$} \\
\hline & Herd A & Herd B & Herd A & Herd B \\
\hline 5 & 7 (12.9) & $11(31.4)$ & 1 & 0 \\
\hline 6 & $3(5.5)$ & $9(25.7)$ & 1 & 5 \\
\hline 7 & $11(20.3)$ & $1(2.8)$ & 3 & 6 \\
\hline 8 & $10(18.5)$ & $4(11.4)$ & 5 & 11 \\
\hline 9 & $14(25.9)$ & $4(11.4)$ & 6 & 14 \\
\hline 10 & $9(16.6)$ & $6(17.1)$ & 9 & 14 \\
\hline
\end{tabular}

${ }^{*}$ Heavily infected ticks defined as those ticks carrying at least 3.0 kinetes per microscope field of haemolymph (Guglielmone et al., 1989).

Table II. - Number and percentage of Boophilus microplus engorged female ticks from two herds of Holstein heifers first found infected with kinetes of Babesia spp. and absolute number of heavily infected ticks in relation to days post-collection.

\begin{tabular}{|c|c|c|c|c|c|c|c|c|c|c|c|c|}
\hline & \multicolumn{7}{|c|}{ Days post-collection } & \multicolumn{5}{|c|}{ Sequential days of infection } \\
\hline & 5 & 6 & 7 & 8 & 9 & 10 & 1 st & 2nd & $3 \mathrm{rd}$ & 4 th & 5 th & 6th \\
\hline \multicolumn{13}{|l|}{ Herd A } \\
\hline$n$ & 7 & 6 & 19 & 24 & 37 & 45 & 54 & 27 & 26 & 18 & 8 & 5 \\
\hline$x$ & 1.7 & 2.5 & 5.6 & 9.5 & 2.6 & 5.1 & 0.5 & 1.9 & 6.2 & 13.8 & 11.2 & 22.9 \\
\hline sd & 3.78 & 5.28 & 16.88 & 23.21 & 9.13 & 11.58 & 1.59 & 5.14 & 16.08 & 25.91 & 18.63 & 20.50 \\
\hline Median & 0.1 & 0.2 & 0.2 & 0.2 & 0.3 & 0.3 & 0.1 & 0.2 & 0.5 & 1.0 & 3.8 & 3.8 \\
\hline $1 \mathrm{Q}$ & 0.1 & 0.1 & 0.1 & 0.1 & 0.1 & 0.1 & 0.1 & 0.1 & 0.2 & 0.3 & 0.4 & 25.3 \\
\hline $3 \mathrm{Q}$ & 1.1 & 4.3 & 1.0 & 0.9 & 1.0 & 1.3 & 0.2 & 1.0 & 2.8 & 14.1 & 14.4 & 42.6 \\
\hline Range & 0.1 & 0.1 & 0.1 & 0.1 & 0.1 & 0.1 & 0.1 & 0.1 & 0.1 & 0.1 & 0.1 & 0.1 \\
\hline & -10.3 & -13.3 & -73.0 & -85.0 & -55.2 & -46.1 & -10.3 & -24.0 & -73.0 & -85.0 & -55.2 & -46.1 \\
\hline \multicolumn{13}{|l|}{ Herd B } \\
\hline$n$ & 11 & 17 & 16 & 22 & 25 & 30 & 35 & 19 & 20 & 18 & 19 & 10 \\
\hline$x$ & 0.4 & 4.7 & 6.4 & 10.5 & 24.6 & 42.0 & 0.4 & 4.0 & 5.8 & 13.6 & 33.4 & 117.4 \\
\hline sd & 0.49 & 8.22 & 12.39 & 19.08 & 41.66 & 77.11 & 0.58 & 7.70 & 11.09 & 20.18 & 43.69 & 97.57 \\
\hline Median & 0.2 & 0.5 & 0.4 & 2.0 & 3.0 & 2.0 & 0.1 & 0.1 & 1.0 & 5.0 & 12.0 & 110.0 \\
\hline $1 \mathrm{Q}$ & 0.1 & 0.1 & 0.1 & 0.2 & 0.7 & 0.1 & 0.1 & 0.1 & 0.5 & 1.0 & 3.0 & 27.8 \\
\hline $3 \mathrm{Q}$ & 1.0 & 5.0 & 4.5 & 16.0 & 33.5 & 39.2 & 0.2 & 3.0 & 4.8 & 19.0 & 47.0 & 192.5 \\
\hline Range & 0.1 & 0.1 & 0.1 & 0.1 & 0.1 & 0.1 & 0.1 & 0.1 & 0.1 & 0.1 & 0.1 & 0.1 \\
\hline & -1.5 & -25.0 & -44.0 & -82.0 & -156.0 & -280.0 & -3.0 & -25.0 & -44.0 & -82.0 & -156.0 & -280.0 \\
\hline
\end{tabular}

Table III. - Mean number ( $x$ ), standard deviation (sd), median, first quartil (1 Q), third quartil (3 Q) and range of kinetes of Babesia spp. per microscope field of haemolymph of Boophilus microplus engorged female ticks from two herds of Holstein heifers according to days post-collection and to sequence of days of infection. 
0.3 kinetes/microscope field of haemolymph at the first detection of infection ( $\mathrm{P}=0.980)$. On the other hand, regarding ticks infected throughout all sampling period, only 1 of the 5 ticks ( $20 \%$ ) of herd A, while none of herd $B(n=10)$ (Fisher exact test, $P=0.375)$ showed this low level of infection on the sixth day.

Babesia spp. kinetes were not detected in twenty one (38.8\%) and $13(37.1 \%)$ infected ticks from herds A and $\mathrm{B}$, respectively, in at least one sample $(\mathrm{P}=0.912)$. Most of these negative determinations (95.2\% in herd $\mathrm{A}$ and $92.3 \%$ in herd B, Yates' corrected chi square $=0.566$ ) were preceded by haemolymph infections lower than 0.3 kinetes/microscope field.

No significant differences were found in the proportion of infected ticks detected when sampling on days 9 and 10 in relation to sampling from days 8 to 10 post collection (table IV). However, all infected ticks of both herds would have been found if sampling consecutively on days 8,9 an 10 post collection.

\begin{tabular}{lcc}
\hline & Herd A & Herd B \\
\hline Total infected ticks from days & 54 & 35 \\
5 to 10 post-collection & & \\
Day 10 & $45^{\mathrm{a}}(83)$ & $30^{\mathrm{a}}(86)$ \\
Days 9 and 10 & $51^{\mathrm{ab}}(94)$ & $33^{\mathrm{a}}(94)$ \\
Days 8,9 and 10 & $54^{\mathrm{b}}(100)$ & $35^{\mathrm{a}}(100)$ \\
\hline
\end{tabular}

Numbers in columns followed by differents superscripts are significantly different at $\mathrm{P}<0.01$.

Table IV. - Number and percentage (in parenthesis) of Boophilus microplus engorged female ticks that would had been found infected with kinetes of Babesia spp. if sampled on day 10, and adding preceding days to detect all ticks infected in relation to the total infected from days 5 to 10 post-collection. Ticks obtained from two herds of Holstein heifers.

\section{DISCUSSION}

A close relationship between daily and cumulative tick infection rates was found. Although up to the $39 \%$ of infected ticks showed at least one negative result in subsequent examinations, most of them followed a low level of haemolymph infection. This did not affect the direct relationship between days post collection and daily infection, including that of heavily infected ticks, as demostrated by the high determination coefficients. This indicates that negative samples of ticks previously found infected were overcame by the proportion of ticks first found infected on each day post collection, and that most of B. microplus engorged female ticks will be consistently detected as infected once they are found in such condition. This last aspect is considered to be result of the amplification of haemolymph infection (Friedhoff, 1988), further supported in the present study by the increasing value of the central positional measures in direct relation to the sequential days of tick infection.

The amplification of haemolymph infection could be shadowed if the infection dynamics is valuated by kinetes number in tick haemolymph on days post collection due to a low level of babesial infection at first detection. Thus, the $42.5 \%$ of infected ticks of herd A was first found infected on the last two days of sampling period, while most of infected ticks of herd $\mathrm{B}$ $(57.1 \%)$ were first found infected on days 5 and 6 post collection. Consequently, those early babesial infections resulted in a higher number of heavily infected ticks in herd $\mathrm{B}$. Temporal differences in the emergence of infection in ticks of both herds could probably be explained by the variability in parasitaemia levels of the bovine tick-hosts, but this aspect was beyond the design of the present study. On the other hand, babesial infection pattern showed similarities in ticks from both herds such as the low level of infection at first detection and the proportion of infected ticks showing negative samples tied to previous low level of infection.

The median, closer to the first than to third quartil, more accurately showed the distribution of Babesia spp. kinetes in the tick haemolymph. This was expected since that distribution correspond to a negative binomial (Gaido \& Guglielmone, 1995), an usual distribution in parasitism (Kennedy, 1975). On the contrary, as stated above, the means were severely distorted by the few ticks carrying a huge number of kinetes indicating that this positional measure is of little value to define the distribution of Babesia spp. kinetes in ticks. This probably can be applied to many other distributions of parasites in their hosts.

Mahoney \& Mirre (1971) showed that sampling B. microplus engorged female ticks haemolymph up to day 7 post collection underestimated the capacity of their progenies to transmit $B$. bovis infection. Present results demonstrated that sampling from days 8 to 10 post collection assured a higher detection of infected ticks. It would be of interest to test the capacity of these ticks progenies to transmit Babesia spp. If this were so, sampling $B$. microplus engorged female ticks after day 7 post-infection would result in a better comprehension of Boophilus-Babesia relationship. However, sampling on those days may be only accomplished in naturally infected ticks since $B$. microplus firstly exposed to $B$. bovis and B. bigemina under laboratory conditions resulted in high mortality of engorged females (Riek, 1964, 1966; Guglielmone et al., 1985, 1995; Mangold et al., 1993) or reduction of egg laying (Davey, 1981: Cafrune et al., 1993). 
According to previous laboratory results, the level of haemolymph infection appears to be a poor indicator of the level of infection in eggs. Thus, Muangyai (1974) showed that a ten fold increase of $B$. bigemina kinetes in the haemolymph of $B$. microplus engorged female resulted in an increase of only $28 \%$ in the egg infection rate, while Cafrune et al. (1995) found that the percentage of $B$. microplus eggs infected with $B$. bovis was independant of the level of haemolymph infection. Therefore, qualitative (infected/non infected) more than quantitative (kinetes number in the haemolymph) status of tick infection appears to be of greater epidemiological importance to cattle babesiosis research. Nevertheless, further field investigations on that relationship are needed to understand if those laboratory results correspond to natural conditions. To this aim, better techniques to differentiate $B$. bovis and $B$. bigemina kinetes in haemolymnph of field ticks are required (Guglielmone et al., 1996).

\section{REFERENCES}

Cafrune M.M., Aguirre D.H., Mangold A.J. \& GuglielMONE A.A. Oviposition in Boophilus microplus infected artificially with Babesia bovis and naturally with $B$. bovis and Babesia bigemina. Annales de Parasitologie Humaine et Comparée, 1993, 68, 196-198.

Cafrune M.M., Aguirre D.H., Mangold A.J. \& GuglielMONE A.A. Studies on Babesia bovis infection rates in Boophilus microplus eggs under experimental conditions. Research in Veterinary Science, 1995, 58, 284-285.

Davey R.B. Effects of Babesia bovis on the ovipositional success of the southern cattle tick, Boophilus microplus. Annals of the Entomological Society of America, 1981, 74, 331-333.

Friedhoff K.T. Transmission of Babesia, in: M. Ristic (ed.), Babesiosis of Domestic Animals and Man. CRC Press, Boca Raton, Florida, 1988, 23-52.

Gaido A.B. \& Guglielmone A.A. Infection dynamics of Babesia spp. kinetes in naturally infected, engorged, female Boophilus microplus. Annals of Tropical Medicine and Parasitology, 1995, 89, 309-311.

Guglielmone A.A., Mangold A.J., Bermudez A.C. \& Hadani A. Detección de infección de Babesia spp. en teleoginas de Boophilus microplus alimentadas sobre terneros con diferentes niveles de parasitemia de Babesia bigemina y Babesia bovis (= Babesia argentina). Revista Ibérica de Parasitología, 1985, 45, 303-311.

Guglielmone A.A., Mangold A.J., Aguirre D.H., Gaido A.B. \& Olsen A.A. The effect of infection by Babesia sp. on some biological parameters of engorged females of Boophilus microplus. Folia Parasitologica, 1989, 36, 1-6.

Guglielmone A.A., Gaido A.B. \& Mangold A.J. Light microscopy diagnosis of Babesia bovis and Babesia bigemina kinetes in the haemolymph of artificially infected Boophilus microplus engorged female ticks. Veterinary Parasitology, 1996, 61, 15-20.
KenNEDy C.R. Reproduction and dispersal, in: Kennedy C.R. (ed.), Ecological Aspects of Parasitology. North Holland Publ. Co., Amsterdam, Oxford, 1975, 143-160.

Mahoney D.F. \& Mirre G.B. Bovine babesiosis: estimation of infection rates in the tick vector Boophilus microplus (Canestrini). Annals of Tropical Medicine and Parasitology, 1971, 65, 309-317.

Mangold A.J., Aguirre D.H., Cafrune M.M., Echaide S.T. \& Guglielmone A.A. Evaluation of the infectivity of a vaccinal and a pathogenic Babesia bovis strains from Argentina to Boophilus microplus. Veterinary Parasitology, 1993, 51, 143-148.

Muangyai M. Quantitative Untersuchugen zur transovarialen Infektion von Boophilus microplus (Ixodoidea) mit Babesia bigemina (Piroplasmea). Veterinary Medicine Dissertation, Veterinary School, Hannover, 1974, 37 p.

RIEK R.F. The life cycle of Babesia bigemina (Smith \& Kilborne, 1893) in the tick vector Boophilus microplus (Canestrini). Australian Journal Agricultural Research, 1964, 15, 802-821.

RIEK R.F. The life cycle of Babesia argentina (Lignières, 1903) (Sporozoa: Piroplasmidae) in the tick vector Boophilus microplus (Canestrini). Australian Journal of Agricultural Research, 1966, 17, 247-254.

Rios L.G., Aguirre D.H. \& Gaido A.B. Evaluación de la dinámica de la infección por Babesia bovis y Babesia bigemina en terneros. Diagnóstico por microscopía directa y prueba de inmunofluorescencia indirecta. Revista de Medicina Veterinaria (Buenos Aires), 1988, 69, 254-256, 258-260.

Rosenbusch F. Estudios sobre la tristeza; evolución del Piroplasma bigeminum en la garrapata (Boophilus microplus Can. Lah.). Boletín del Instituto de Clínica Quirúrgica (Buenos Aires) 1927, 3, 347-351.

Reçu le 3 décembre 1996 Accepté le 21 août 1997 